\title{
Modular Distance Learning Expenses of Senior High School Teachers amidst the Pandemic
}

Cristoni A. Macaraeg, Jall R. Barcelo, Dory Nell G. Reyes, Monica E. Merculio, Jewel A. Bernardo, Mercedes D. Santos

Masters in Business Administration, Graduate School, Nueva Ecija University of Science and Technology, Cabanatuan City, Philippines

Received: 19 Mar 2021; Received in revised form: 25 April 2021; Accepted: 18 May 2021; Available online: 11 Jun 2021 (C)2021 The Author(s). Published by Infogain Publication. This is an open access article under the CC BY license (https://creativecommons.org/licenses/by/4.0/).

\begin{abstract}
This descriptive study focused on the Modular Distance Learning (MDL) expenses of Muñoz National High School - Main Senior High School (MNHS-Main SHS) teachers during the COVID-19 pandemic. Fifty-five teachers were the respondents of the study. Data gathering was done online, a digitized version of the researcher-devised questionnaire was accomplished by the respondents through Google Forms. Basic descriptive statistics such as frequency, ranking, and percentage were utilized to compute the data. Results of the study show that for the $1^{\text {st }}$ semester of the S.Y. 2020-2021, teachers have incurred at most 4,000 pesos monthly for the aforesaid supplies and allowances. Delayed release of allowances, bonuses, and other incentives leads teachers to incur out-of-pocket expenses. MDL implementation can put teachers' health at risk during module distribution and retrieval, resulting in an increase in workload for teachers, particularly when it comes to sorting and packing modules, as well as additional costs for school and office supplies, health and safety supplies, transportation allowances, and communication allowances. Thus, the study suggested that reimbursement procedures and requirements should be eased for a faster grant. A cellphone should be allotted by the school for teachers to communicate with their students and their parents. Moreover, teachers should be given access to the school's internet connection for effective communication and attendance at webinars. DepEd should also speed up its release of delayed allowances, bonuses, and other incentives.
\end{abstract}

Keywords-Communication allowances, expenses, health and safety supplies, modular distance learning, school and office supplies, transportation allowances.

\section{INTRODUCTION}

The impact of the Covid-19 pandemic on every institution in the Philippines, including education, is undeniable. To minimize the spread of the fatal disease, the Department of Education (DepEd) suspended face-to-face classes from primary to secondary level, until safe. As stated in DepED Order No. 012, s. "2020 entitled Adoption of the Basic Education Learning Continuity Plan (BE-LCP) for School Year 2020-2021. The department developed a package of education interventions that will respond to basic education challenges amidst the pandemic" [1]. BE-LCP streamlines $\mathrm{K}$ to 12 "into the Most Essential Learning Competencies (MELCs), to be delivered in multiple learning modalities or platforms. Distance Learning modalities include Modular Distance Learning (MDL), Online Distance Learning (ODL), and TV/Radio-Based Instruction (TBI/RBI), depending on the Covid-19 restriction of the community and the context of the school".

Santos (2020) writes that MDL is the most common form of distance learning for $\mathrm{K}$ to12 students, in which class modules are printed out for students to study on their own and submit to teachers for grading. Head of Teachers Dignity Coalition (TDC), Benjo Basas claimed that MDL has created extra work for the Philippines' 42,000 public school teachers. Additional workload and health risks are 
not the only concerns of teachers in MDL, for it means additional expenses too, Basas adds that there are teachers begging for donations of bond paper and ink to print modules [2].

Although MDL is the most cost-efficient alternative learning delivery mode among others [3], and DepEd gets a huge chunk of the 2021 budget allocation, specifically P606.6 billion, 9.54 percent higher than in 2020 which was P552.9 billion [4], still teachers' incurrence of MDLrelated expenses is inevitable. Furthermore, as teachers welcomed the provision in the signed 2021 budget increasing the annual teaching allowance from P3500 to P5000, the Alliance of Concerned Teachers (ACT), through its Secretary-General Raymond Basilio, said the amount is still "totally short" for teachers' expenses for distance education [5].

Meanwhile, the same is true in foreign countries. Byun and Slavin's study (2020) finds out that teachers in South Korea need to pester parents and their children by texting, messaging, and calling regarding the latter's lessons during the pandemic [6]. In India, teachers are recommended to be in touch with their students in order to keep them motivated during the lockdown [7].

In the Philippines, Tagupa (2018) reports that many teachers are often with left no choice but to spend their own salaries for the needs they should not be shouldering from school activities to classroom posters and furniture including teachers' tables and chairs. They call it "classroom beautification" which is a big deal for them that they need to handle it themselves or it would affect their ratings [8]. These spendings are sometimes reimbursed and most of the time not.

MOOE fund or school monthly fund, based on DepEd Order No. 013, s. 2016 entitled Implementing Guidelines on the Direct Release and use of MOOE Allocations of Schools, Including Other Funds Managed by Schools, are given to public schools in the country [9]. Nonetheless, allocation of this fund merely focuses more on the basic needs of the school which focuses merely on its utilities and repair and maintenance. "A detailed costing study by the World Bank (2016) that existing levels of school MOOE funding remain insufficient despite increases and would need to more than double to satisfy existing service standards" [10].

A new learning delivery modality brings a new set of expenses. Muñoz National High School - Main Senior High School (MNHS-Main SHS) implements MDL for S.Y. 2020-2021, with the students and their parents' preferences and resources in consideration. The school administration is providing its teachers what are available school supplies for sorting modules and printing reports, as well as hygiene supplies and transportation allowances to be used during module distribution/retrieval. Also, the teachers have already received a portion of their communication allowance from DepEd amounting to almost 600 pesos, for contacting parents and students and attending webinars online. However, questions would still direct to the sufficiency of these supplies and allowances.

Since MDL is an entirely new learning delivery mode in the country, the researchers find it timely and relevant to conduct this study. It described the expenses, and problems incurred by MNHS-Main SHS teachers during the implementation of MDL amidst the pandemic.

\section{METHODOLOGY}

The study employed a descriptive design. Balaria et al. (2018) state that the descriptive method attempts to describe the present condition [11]. Only 55 teachers of Muñoz National High School - Main Senior High School served as respondents. Data gathering was done online after the first semester of the School Year 2020-2021. The digitized form survey questionnaire was utilized with Google Forms as the platform. Answered questionnaires were downloaded and data were subjected to interpretation. Basic descriptive statistics such as frequency, percentage, and ranking were used.

\section{RESULTS AND DISCUSSIONS}

1. Description of the expenses incurred by the teachers for Modular Distance Learning.

Table 1 shows the expenses the teachers have incurred in providing supplementary school and office supplies.

Table 1. Expenses incurred by Teachers on School and Office Supplies

\begin{tabular}{lcc}
\hline School and Office Supplies & $f^{*}$ & Rank \\
\hline Bond papers & 44 & 1 \\
Folders & 25 & 7 \\
Envelopes & 31 & 4 \\
Class records & 16 & 10 \\
Stapler & 28 & 5.5 \\
Staple wires & 33 & 3 \\
Inks for printer & 38 & 2 \\
Storage boxes & 28 & 5.5 \\
Books & 11 & 11 \\
Supplemental instructional/reference materials & 23 & 9 \\
Gadgets (Deped Tablet) & 24 & 8
\end{tabular}


None

0

* Multiple responses

The school and office supplies respondents incurred the most expenses on are Bond papers, rank 1 with 44 responses, while the least purchased are books, with 11 responses. Also, none of the respondents, rank 12, answered None which means that all of them have incurred expenses for school and office supplies. Bond papers are the most purchased by the teachers since these are utilized almost daily for printing reports, additional activity sheets of students, and other paper works. Sometimes, when teachers do not have extra money to spend, they would resort to soliciting donations. Under the "Bond Paper Mo, Module Ko" online campaign on their Facebook profiles, teachers and schools post that they are accepting bond paper donations for this year's Brigada Eskwela [12]. Meanwhile, Orejas (2020) writes that "teachers in Central Luzon provinces have been advised not to solicit reams of bond papers from parents for the printing of modules. Nicolas Capulong, regional director of DepEd issued the reminder and said the printing of modules is funded by the agency's central office" [13].

On the other hand, only a few incurred expenses on books since there are books provided by the school's Learning Resource Management System and Development (LRMDS). In addition, based on Deped Order No. 012, s. 2020, "the Most Essential Learning Competencies (MELCs) will be the guide of the subjects for S.Y. 20202021, and lessons from the books will be compressed into modules" [1]. Capulong (2020) further emphasizes that "modules are designed according to knowledge and competencies that students of certain levels must develop and master in the K to 12 curriculum" [13].

In order to continue delivering quality education amidst the pandemic, the health condition of the teachers is the top priority, hence they tend to spend for additional health and safety supplies on their own, as described in Table 2, in response to the problems they have encountered on them.

\section{Table 2. Expenses incurred by Teachers on Health and} Safety Supplies

\begin{tabular}{lcc}
\hline Health and Safety Office Supplies & $f^{*}$ & Rank \\
\hline Alcohol & 48 & 1 \\
Hand sanitizer & 23 & 5.5 \\
Face masks & 44 & 2 \\
Handwash/hand soaps & 23 & 5.5 \\
Face shields & 39 & 3
\end{tabular}

$$
\text { Paper towels }
$$

$20 \quad 8$

Gloves

Disinfectants

$30 \quad 4$

Personal Protective Equipment

$22 \quad 7$

Plastic barriers

$14 \quad 10$

None

159

0

* Multiple responses

Alcohols, rank 1 with 48 responses, are the health and safety supplies most purchased by the teachers, whereas Personal Protective Equipment (PPE) is the least acquired, rank 10 with 14 responses. In addition, none of the respondents chose none, rank 12 , implying that all of them have also spent their own money on health and safety supplies.

Alcohols got the highest ranking in the health and safety the teachers have incurred the most expenses on which means that teachers need more of it. Meanwhile, PPE is given to teachers by the school to be worn during module distribution and retrieval, thus they do not have to buy on their own to be used for the following schedules. According to the Center for Medical Ethics and Health Policy (2020), reusable PPE is more cost-effective since institutions would no longer spend large amounts regularly on the disposable standard. Furthermore, reusable PPE reduces natural resource energy consumption, greenhouse gas emissions, total water consumption, and solid waste generation [14].

With the time there was the unavailability of health and safety supplies due to limited and prioritization of fund, teachers need to provide for themselves because aside from merely following protocols, they also have a critical role to play in ensuring parents and students understanding the precautions they should take to protect themselves and other from Covid-19, and it is important they lead by example in the school or any other places [15]. Moreover, "it is the task of the teachers to make sure that they could deliver and retrieve modules on time, communicate with the students and their parents well, and continuously strive for professional development"[15]. Thus they strategize and address the problems through shouldering certain transportation and communication allowances, as illustrated in Table 3.

Table 3. Expenses incurred by Teachers on Communication and Transportation Allowances

\begin{tabular}{llcl}
\hline Communication & and & Transportation & $f^{*}$ Rank \\
Allowances
\end{tabular}




\begin{tabular}{|c|c|c|}
\hline Transportation for module distribution & 30 & 5 \\
\hline Transportation for module retrieval & 27 & 7 \\
\hline $\begin{array}{l}\text { Transportation for coordinating with } \\
\text { barangay centers }\end{array}$ & 28 & 6 \\
\hline Allowance for monthly internet connection & 38 & 2 \\
\hline $\begin{array}{l}\text { Mobile data allowance for contacting } \\
\text { students/parents }\end{array}$ & 34 & 4 \\
\hline $\begin{array}{l}\text { Mobile data allowance for attending } \\
\text { webinars }\end{array}$ & 37 & 3 \\
\hline $\begin{array}{l}\text { The load allowance for calling/texting } \\
\text { students/parents }\end{array}$ & 39 & 1 \\
\hline None & 0 & 8 \\
\hline
\end{tabular}

* Multiple responses

The communication expenses teachers spent the most on is the Load allowance for calling/texting students/parents, rank 1 with 39 responses, while the lowest responses, 27 on rank 7, were given to Transportation for module retrieval. Also, none of the teachers, rank 8, answered None, meaning they have all incurred expenses on transportation and communication.

Though allowances are available to teachers, these are most of the time given late to them, forcing them to spend their own money instead and anticipate reimbursements. Relative to this, ACT Secretary-General Raymond Basilio said "teachers have not fully benefitted from the reimbursement due to insufficient school funds, stringent requirements, poor information dissemination about the directive, and inconsistent execution of the order on the ground' [16]. "Furthermore, the Teacher's Dignity Coalition (TDC) stated that it has received concerns regarding difficulties in reimbursing communication expenditures and has requested that the reimbursement procedure be made as simple as possible for teachers". Heads of offices must give a certification identifying people who are entitled to claim reimbursement for communication expenditures, according to the regulation. They also need to affirm that "these expenses were incurred in the performance of their official duties and responsibilities." According to the order, "personnel is also asked to provide proof of purchase or payment, such as an official receipt for the purchase of a prepaid card or payment of a postpaid line or internet subscription, among others" [16].

To quantify the expenses teachers have incurred on the implementation of MDL for the first semester of the S.Y. 2020-2021, Table 4 presents their average monthly expenses per supplies and allowances category based on the survey.

Table 4. Average Monthly Expenses incurred by Teachers on MDL based on the survey

Average expenses per month (Philippine peso)

\begin{tabular}{lcccccccccc}
\hline \multicolumn{1}{c}{$\begin{array}{c}\text { Supplies and } \\
\text { Allowances }\end{array}$} & \multicolumn{1}{c}{ below P1,000 } & $\mathbf{P 1 , 0 0 0 - P 2 , 0 0 0}$ & $\mathbf{P 2 , 0 0 0 - P 3 , 0 0 0}$ & $\mathbf{P 3 , 0 0 0}$ above & \multicolumn{2}{c}{ Total } \\
\cline { 2 - 10 } & $F$ & $\%$ & $f$ & $\%$ & $F$ & $\%$ & $f$ & $\%$ & $F$ & $\%$ \\
$\begin{array}{l}\text { School and office } \\
\text { supplies }\end{array}$ & 38 & 69.09 & 13 & 23.64 & 1 & 1.82 & 3 & 5.45 & 55 & 100 \\
$\begin{array}{l}\text { Health and safety } \\
\text { supplies }\end{array}$ & 35 & 63.64 & 14 & 25.46 & 3 & 5.45 & 3 & 5.45 & 55 & 100 \\
$\begin{array}{l}\text { Transportation } \\
\text { expenses }\end{array}$ & 32 & 58.18 & 19 & 34.55 & 1 & 1.82 & 3 & 5.45 & 55 & 100 \\
$\begin{array}{l}\text { Communication } \\
\text { expenses }\end{array}$ & 24 & 43.64 & 23 & 41.81 & 6 & 10.91 & 2 & 3.64 & 55 & 100 \\
\hline
\end{tabular}

With regard to school and office supplies, the majority of the teachers, $38(69.09 \%)$ spent less than 1,000 pesos, while only one $(1.82 \%)$ spent approximately 2,000 to 3,000 pesos a month. As to health and safety supplies, 35 respondents $(63.64 \%)$ said they incurred expenses below 1,000 pesos and 2,000 to 3,000 pesos, and 3,000 pesos above both got three responses each (5.45\%). For transportation expenses, most of the respondents, 32 $(58.18 \%)$, spent less than 1,000 , however only one spent 2,000 to 3,000 pesos monthly. In terms of communication expenses, 24 respondents $(43.63 \%)$ have incurred expenses amounting to below 1,000 pesos whereas only two incurred expenses above 3,000 pesos a month. In general, the majority of the teachers approximately incurred 4,000 pesos out-of-pocket expenses monthly for the implementation of MDL during the $1^{\text {st }}$ semester. The data gathered in the study based on the survey support the claim of Basas of TDC that MDL implementation can post health risk, increase of workloads due to long preparations of printed modules which leads to additional expenses to 
public school teachers [2]. In relation to this, "Basilio of ACT proposed to DepEd the release of delayed teachers' benefits such as the performance-based bonus from 2019 and service recognition incentives from 2020" [17]. "Releasing these bonuses and incentives would compensate the expenses teachers have already incurred for MDL, considering that they are still in the middle of the school year"[17]. Moreover, "ACT reiterated its request for the government to give 1,500 pesos per month to education workers who are working from home, adding that it should not be charged from their salaries. Nevertheless, DepEd has not yet responded on the issue as of writing" [17]. Favorably responding to the request of the teachers would help the teachers in providing these supplies and allowances to lessen the burden they already carrying brought about by health risks and increased workloads amidst the Covid-19 pandemic.

\section{CONCLUSIONS AND RECOMMENDATIONS}

The study on the MDL expenses of MNHS-Main SHS teachers revealed that teachers incurred average monthly expenses of less than 1,000 pesos each on school and office supplies, health and safety supplies, transportation allowance, and communication allowance amidst the COVID-19 pandemic [18]. The delay in the release of communication allowance, bonuses, and other incentives leads the teachers to incur out-of-pocket expenses. Also, the process and requirements for reimbursing their expenses are hard. MDL implementation can pose health risks to teachers [19] during module distribution and retrieval, and which leads to an increase of workload to teachers, most especially on sorting and packing modules and the long preparations of printed modules, and the reason of incurring additional expenses on their part for school and office supplies, health and safety supplies, transportation allowances, and communication allowances which cannot be all accommodated by the limited MOOE fund. Based on the findings and conclusions the researchers suggest the following [20]: Hard copies of reports and other paper works should be lessened. Teachers should be given help in sorting modules and packaging the learning materials of their students to avoid sacrificing actual teaching responsibilities. Transportation allowances should be given prior to module distribution and retrieval. A cellphone or two should be allotted by the school for the teachers to use in communicating with their students and their parents. All teachers should be given access to the school's internet connection to be utilized for communication with students and their parents, and attendance to webinars. The expenses incurred by the teachers on MDL during the $1^{\text {st }}$ semester of the S.Y. 20202021 should be duly reimbursed, as well as their future expenses. The process and requirements for reimbursements should be eased and lessened. Delayed bonuses, incentives, and allowances should immediately be released by DepEd and the physical and mental health of the teachers should always be put into consideration for they are also adapting to this entirely new learning delivery modality.

\section{REFERENCES}

[1] Adoption of the Basic Education Learning Continuity Plan (BE-LCP) for School Year 2020-2021 in Light of the Covid-19 Public Health Emergency. DepEd Order No. 012, s.2020.

[2] Santos, A. (October 6, 2020). In the Philippines, distance learning reveals digital divide. Heinrich-Bol-Stiftung. https://eu.boell/org/en/2020/10/06/philippines-distancelearning-reveals-digital-divide

[3] Potashnik, M. \& Capper, J. (2013). Distance education: Growth and diversity. World Bank's Education and Technology Team Journal, pp. 123-126.

[4] Nazario, D. (August 31, 2020). DepEd gets p606.6-B under 2021 nat'l budget. Manila Bulletin. Retrieved from https;//mb.com.ph/2020/08/31/deped-gets-p606-6-b-under2021-natl-budget/

[5] Magsambol, B. (December 1, 2020). Teachers' group: p5,000 annual allowance 'totally short' for distance education. Rappler.com. https://www.rappler.com/nation/teachers-group-5000annual-teaching-allowance-inadequate-distance-education

[6] Byun, S., \& Slavin, R.E. (2020) Educational responses to the COVID-19 outbreak in South Korea. Best Evid Chin $E d u$, 5(2):665-680.

[7] Gupta, A. \& Goplani, M. (May 2020). Impact of COVID19 on educational institution in India. Purakala Journal U(CARE Listed), 31(21).

[8] Tagupa, H. (2018) Are PH teachers really underpaid?. Philippine Daily Inquirer. https//:www.opinion.inquirer.net/114243/phteachers-reallyunderpaid/amp

[9] Implementing Guidelines on the Direct Release and use of Maintenance and Other Operating Expenses (MOOE) Allocations of Schools, Including Other Funds Managed by Schools. Department of Education Order No. 13, s. 2016.

[10] World Bank (2016). The Development and implementation of a Normative School MOOE Formula in the Department of Education in the Philippines. World Bank, Washington D.C.

[11] Balaria, F. E. et.al. Principles of Research (for classroom discussion only), 2018 edition

[12] Arroyo, L. (2020). Teachers, schools seek paper supply donations for printing modules. Rappler.com. https://www.rappler.com/moveph/papers-please-teacherscrowdsource-bond-papers-online-ease-burden-printingmodules 
[13] Orejas, T. (2020). Teachers told: Modules financed by gov't, stop soliciting donations. Inquirer.net. https://newsinfo.inquirer.net/1306734/teachers-toldmodules-fiannced-by-govt-stop-soliciting-donations/amp

[14] Center for Medical Ethics and Health Policy (202). An argument for reusable PPE. Baylor College of Medicine. https;//blogs.bcm.edu/2020/05/07/an-argument-forreusable-ppe/

[15] United Nations Children's Fund (2020). Classroom precautions during Covid-19: Tips for teachers to protect themselves and their students. https://www.unicef.org/coronavirus/teacher-tips-classroomprecautions-covid-19

[16] Malipot, M. (2021). Teachers ask DepEd to 'reimburse P300-communication allowance to all'. Manila Bulletin. https://mb.com.ph/2021/01/11/teachers-ask-deped-toreimburse-p300-communication-allowance-to-all/

[17] ABS-CBN News (2021). Teachers ask DepEd for quick reimbursement of P300 communication allowance. https://www.abs-cbn.news/amp/news/01/12/211/teachersask-edped-for-quick-reimbursement-of-p300communciation-allowance

[18] Mina, J.C., Subia, G.S., Barlis, P.T., Tuliao, R.C. and Pastorfide, P.M. (2020). Inclinations of Engineering and Marketing Management Students to Engage in Online Learning Technology Amidst the COVID-19 Pandemic. Technology Reports of Kansai University, ISSN: 04532198, Volume 62, Issue 09

[19] Millicent Marie W. Subia, Marie Jo G. Callanta, Rhoda T. Razon, Gener S. Subia. (2021). Cholesterol, Glucose and Blood Pressure Levels of the Department of Education Employees towards Effective Health Care Monitoring System. Annals of the Romanian Society for Cell Biology, 4873-4878. Retrieved from https://www.annalsofrscb.ro/index.php/journal/article/view/ $\underline{633}$

[20] Mina, J.C., Barlis, P.T., Vega, N.C. and Subia, G.S. (2019) Corporate Social Responsibilities of Selected Resorts in Cabanatuan City, Nueva Ecija, Philippines. Open Access Library Journal, 6: e5292. https://doi.org/10.4236/oalib.1105292 